\title{
Development of Mathematics Module Framed In Nuance Of Islam Through Scaffolding Method
}

\author{
Fitri Mulianda, Nirva Diana, Dian Anggraini \\ Pendidikan Matematika, Tarbiyah, UIN Raden Intan Lampung \\ fitri.10mulianda@gmail.com
}

\begin{abstract}
The purpose of this research is in order to know the development, appropriateness, attractiveness and effectiveness of product developed in Al-Kautsar Bandar Lampung senior high school and MAN 2 Bandar Lampung. The procedure used is resert and development with research method and the 4-D development initiated by Thiagarajan. The data collection instrument conducted by spreading appropriateness questionnaires to the subject expert, media expert, religion expert, and education practitioner, deployment of appropriateness questionnaires to students in small scale trial and big scale trial and giving pre post test in effectiveness trial using $\mathrm{N}$-Gain calculation. Obtained effectiveness result in the amount of 3,6 from subject expert, 3,5 from media expert, and 3,7 from religion expert, then its average is 3,6 . It gets "very decent barometer". The students' response showed that the module is very interesting with average 3,47 from both schools with "very decent criteria" on small scale trial and 3,3 with "very decent criteria" on big scale trial. The result of effectiveness trial got 0,77 at SMA AlKautsar Bandar Lampung and 0,72 at MAN 2 Bandar Lampung. Based on Gain score range that is $G \geq 0,7$, so mathematics module framed in nuance of Islam through scaffolding on aljabar function limit subject is categorized with high classification.
\end{abstract}

Keywords: Development, Module, Islam, Scafflding

\section{INTRODUCTION}

Education is a means to increase nation progress. Trhough education, a man will be considered more honored and could have a better career and behave in accordance with applicable norms. Edication is a role to develop and form personalities and behaviour for each individual to be noble, educated, skilled, and religious human being and devote to ALLAH SWT (Fiska, Farida \&Syazali, 2016). Therefore we need the education giving us knowledgeable values to form educated and religious personalities and it is Islam. Islamic values can be mixed in learning especially in mathematics learning (Mulya, Netriwati \& fraulein, 2018).

Education framed in Islamic nuance and consiting of islamic values in mathematics subject at Madrasah and Islam Universities recently has been developed. According to Supriadi (2007) these islamic values differentiate common schools and universites from Madrasah and IslamicUniversities which are dominated by islamic values applied. Islamic nuance itself is about intergrating mathematical science with in 
general with Islam without having to eliminate the uniqeness of those two sciences. The Islamic nuances in this mathematical module are illustrated in the module design with Islamic nuances, the verses of the Qur'an and Muslim scientists as motivations in learning, and mathematical material that is associated with Islamic values without changing the competency standards contained in the curriculum having been applied. Based on preface study, the problem is that the independence of students is still low in the mathematics learning process. This is because the teaching materials used by students so far only consists of mathematical material and questions without the help needed by students so that this problem makes students feel difficult to understand the lesson and to solve math problems if without guidance from educators. Thus, we need a teaching method that can provide assistance gradually so that students want and are able to solve mathematical questions independently both inside and outside the school environment. The method required by students is the scaffolding method.

According to Trianto (2014) Scaffolding provides some assistance to students during the early stages of learning then the students take over the responsibility that is bigger shortly after they are able to do it. The assistance can be in the form of instructions, warnings, motivation, encouragement, describing the problem in the steps of solving, giving examples, or others so that this is possible for students to grow independently. Scaffolding in this study will be applied in the contents of the module.

The research on modules conducted by Lidya Alimah Fitri, Eko Setyadi Kurniawan and Nur Ngazizah with the results of the study showed that the quality of the module developed was categorized good and feasible for physics learning (Lidya, Eko \& Nur, 2013). Next, the module framed in nuance of Islam by Mulya Diana received responses from students with an average score $89.0061 \%$ with very interesting criteria and responses of educators with an average score of $85.490196 \%$ with very decent criteria (Diana, Netriwati \& Fraulein, 2016). The research on scaffolding was also carried by Nicke Septriani. Irwan and Meira stated that students' ability with the scaffolding approach is better than students' understanding on mathematics concept with conventional learning (Nicke, Irwan \& Meira, 2014).

The use of module can increase knowledge for students in learning process. So, it is necessary to develop module framed in nuance of Islam based onscaffolding. Therefore, the researcher is interested in conducting research entitled Development of Mathematics ModuleFramed in Islam Nuancethrough scaffolding on Material of Algebraic Functions.

\section{RESEARCH METHOD}

The study was conducted by using a type of research and development. Sugiono (2017) argued that research and development or Research and Development (R\&D) is a research method to produce a particular product and evaluate the effectiveness fro the product. The research model used is 4-D initiated by Thiagarajan, and 4-D model is used in this study because it has been widely used in research and education development and 
is more systematic by only having four main stages which are define, design, develop, dessimanate.

Data collection instruments used were validation sheets given to validator and edication parctitioners, while trial questionare sheets on small group trials and field trials as well as pretest and posttest questons to calculate the effectiveness of the products developed. The product developed was validated by material expert, media expert, and education pratitioner, and then the product is improved according to the advice given experts until the product was declared feasible. After being declared feasible, then the product was tested on a small group and field to assess the product attractiveness. The test on a small group and field was conducted by giving products which was declared feasible and giving the product attractiveness questionaires to students. The total assessment score of the validation and trial can be found by using the following formula:

$$
\bar{x}=\frac{\sum_{i=1}^{n} x i}{n}
$$

with :

$$
\mathrm{x}_{\mathrm{i}}=\frac{\text { Total Score }}{\text { Maximum Number of Score }} \mathrm{x} 4
$$

Inormation :

$\overline{\mathrm{x}}=$ Final average

$\mathrm{x}_{\mathrm{i}}=$ The operational test scores of each student's questionnaire

$\mathrm{n}=$ The number of students who fiiled out the questionnaire

The result scores from the expertswere counted for the averages and coverted to determine the feasibility of the product developed. The average analysis feasiblity criteria can be seen in Table 1:

Table 1.Criteria Validation (modification).

\begin{tabular}{ccc}
\hline Quality Score & Eligibility Criteria & Information \\
\hline $\mathbf{1}, \mathbf{0 0}<\overline{\boldsymbol{x}} \leq \mathbf{1 , 7 6}$ & Invalid & Total Revision \\
$\mathbf{1}, \mathbf{7 6}<\overline{\boldsymbol{x}} \leq \mathbf{2 , 5 1}$ & Less Valid & Partial Revision \\
$\mathbf{2}, \mathbf{5 1}<\overline{\boldsymbol{x}} \leq 3,26$ & Quite Valid & Partial Revision \\
$\mathbf{3}, \mathbf{2 6}<\overline{\boldsymbol{x}} \leq \mathbf{4}, \mathbf{0 0}$ & Valid & Not Revised \\
\hline
\end{tabular}

The results of the assessment of each participant are promoted on average and converted to determine the product attractiveness. The conversion score can be seen in Table 2 below: 
Table 2. Criteria for attractiveness test (modification).

\begin{tabular}{cc}
\hline Quality Score & Eligibility Criteria \\
\hline $\mathbf{1 , 0 0}<\overline{\boldsymbol{x}} \leq \mathbf{1 , 7 6}$ & Very Less Interesting \\
$\mathbf{1 , 7 6}<\overline{\boldsymbol{x}} \leq \mathbf{2 , 5 1}$ & Less attractive \\
$\mathbf{2 , 5 1}<\overline{\boldsymbol{x}} \leq 3,26$ & Interesting \\
$\mathbf{3 , 2 6}<\overline{\boldsymbol{x}} \leq \mathbf{4 , 0 0}$ & Very interesting \\
\hline
\end{tabular}

After the feasibility test by the validators and the attractiveness test by the students, the product is tested for its effectiveness. The effectiveness test was carried out on 30 students of class XI by giving pretest questions before learning with modules, and giving posttest questions after learning with the module.Effectiveness is seen by comparing the results of the pretest and posttest by using the N-Gain calculation.Gain is the difference between the pretest and posttest values to find out an increase in understanding and mastery of concepts of students after the learning process carried out by educators. The effectiveness test of the pretetest and postetest was calculated by using N-Gain with the following formula:

$$
N N-\text { Gain }=\frac{S_{\text {post }} S_{\text {post }}-S_{\text {pre }} S_{\text {pre }}}{S_{\text {maks }} S_{\text {maks }}-S_{\text {pre }} S_{\text {pre }}}
$$

Information:

$S_{\text {post }}$ : final test score

$S_{\text {pre }} S_{\text {pre }}$ : initial test value

$S_{\text {maks }}$ : maximum value

The gain value is interpreted into three criteria, namely high, medium, and low.

The following are the criteria for gain values shown in Table 3 below.

Table 3. Gain Value Categories

\begin{tabular}{cc}
\hline Nilai Gain $(\mathbf{G})$ & Kategori \\
\hline$G \geq 7$ & High \\
$\mathbf{0 , 3}<G<0,7$ & Medium \\
$G<0,3$ & Low \\
\hline
\end{tabular}

\section{RESULTS AND DISCUSSION}

This research produces a product in the form of mathematics module framed in nuance of Islam through scaffolding. The material used is the limit of algebraic functions developed based on the scaffolding method.The research model used in this study is 4-D from Thiagarajan which includes four main stages, namely defining, designing, developing and disseminating.Conceptually the 4-D research procedure includes:

\section{a. Defining}

1. Front-End Analysis

Based on the results of the needs analysis obtained: 
a) Students have difficulties in understanding mathematical material both mathematics concpet and calculations.

b) Students have low independence in process of learning mathematics.

c) Educators have not linked mathematics subject with Ilsamic values.

d) Teaching materials usde by students have not been linked beetwen mathematics and verses of Al-Quran.

2. Concept Analysis

In the module developed, the researcher systematically relevantly compiled limitmaterial on algebraic functions relevant in three chapters including the definition of limit, operation on limit and limit teorema.

3. Task Analysis

Obtaining an example of a question and practice on each chapter of the material for limit of algebraic functions using the scaffolding method.

4. Specifications of Intructional Objectives

Formulating objectives by summarizing the results of front-end analysis, concept analysis and task analysis that aims to determine the behavior of research objects.

\section{b. Design}

1. Contructing criterion referenced test

The high school mathematics module with a scaffolding-based Islamic nuance was chosen as the teaching material developed, and it aims to facilitate and help students be more independent in the learning process.

\section{Format Selection}

The product design arrangement in this module has several steps including adjusting core competencies and basic competencies based on the 2013 curriculum (K13).

\section{Initial Design}

The initial design of the module development product consists of the front cover and back cover, module developer team page, introduction, table of contents, perface, standard content and concept map. While the contents of the module consist of learning activities, verses relating to material limits, Muslim scientific figures as motivation for students, zone of proximal development to see the development of students and scaffolding or assistance that makes it easier for students to understand the material and workmanship questions.

\section{c. Develop}

The activities carried out at this stage are validation of experts (material experts, media experts, religious experts and education practitioners), validation is carried out in two stages to obtain the feasibility of the module. The results of evaluations from experts can be seen in Table 4 . 
Table4. Results of Product Assessment by Experts

\begin{tabular}{lll}
\hline Validator & Average value & Criteria \\
\hline Material Expert & 3,6 & Very Worthy \\
Media Expert & 3,5 & Very Worthy \\
Religionist & 3,7 & Very Worthy \\
\hline
\end{tabular}

After being declared feasible, the module is tested on small group trials and large group trials to assess module attractiveness. The results of the assessment of small groups and large groups can be seen in Table 5 below:

Table 5. Trial Results of Small and Large Groups

\begin{tabular}{lll}
\hline Trial & Average value & Criteria \\
\hline Small Group & 3,4 & Very interesting \\
Field & 3,29 & Very interesting \\
\hline
\end{tabular}

After the module is declared feasible and attractive, the product is tested for effectiveness. The following is the results of calculating the effectiveness of the products presented in Table 6 .

Table 6. Conclusion of Effectiveness Test Results

\begin{tabular}{lll}
\hline Sekolah & N-Gain & Kriteria \\
\hline Al-Kautsar B. Lampung High School & 0,77 & High \\
MAN 2 B. Lampung & 0,72 & High \\
\hline
\end{tabular}

\section{d. Dessiminate}

The distribution is carried out to educators in either the print or the Softfile Module while the mass deployment to students is done by sending the softfile modulethrough the group on the WhatsApp application.

\section{CONCLUSION}

The conclusion of this study is mathematical modules with Islamic nuances through the scaffold method that has obtained the feasibility value from experts of 3.6 with very feasible criteria and an interesting response from 3.4 small group trials with very interesting criteria and response to large group trials 3.29 with very interesting criteria. In the trial, it obtained a value of 0.77 with high criteria in Bandar Lampung AlKautsar High School and 0.72 with high criteria in MAN 2 Bandar Lampung.

Suggestions that can be submitted are mathematical modules with Islamic nuances through the scaffolding method ofthe material presented is only on the limits of algebraic functions so that the development of the next module can be develop 
mathematical modules with Islamic nuances through scaffolding methods on wider material.

\section{REFERENCES}

Alin Wahyu Rizkiah, Nasir Nasir, dan Komarudin Komarudin,. (2018). "LKPD Discussion Activity Terintegrasi Keislaman dengan Pendekatan Pictorial Riddle pada Materi Pecahan," Desimal: Jurnal Matematika,; Vol. 1, no. 1.

Anggoro Bambang Sri,. (2015). "Pengembangan Modul Matematika Dengan Strategi Problem Solvin Guntuk Mengukur Tingkat Kemampuan Berpikir Kreatif Matematis Siswa," Al-Jabar: Jurnal Pendidikan Matematika,; Vol. 6, no. 2.

Astika Finka Fitri,. (2014). "Pengembangan Modul Pada Materi Matriks dengan Pendekatan PMRI untuk Siswa Kelas X SMK," Skripsi. Universitas Negeri Yogyakarta.

Atika Izzatul Jannah And Ending Lutyani, . (2017). "Pengembangan Bahan Ajar pada Bahasan Himpunan dengan Pendekatan Problem Solving untuk siswa SMP kelas VII,“ Jurnal Pendidikan Matematika, S1 6. No. 3

Chairani Zahra,. (2015). "Scaffolding dalam pembelajaran matematika," Math Didactic: Jurnal Pendidikan Matematika, Vol. 1, no. 1,

Cholid Narbuko dan H. Abu Achmadi,. (2009).Metodlogi Penelitian, jakarta: bumi aksara,

Fiska Komala Sari, Farida Farida, dan Muhamad Syazali,. (2016). "Pengembangan Media Pembelajaran (Modul) berbantuan Geogebra Pokok Bahasan Turunan," AlJabar: Jurnal Pendidikan Matematika, Vol. 7, no. 2

Fitri Lidya Alimah,. (2013). "Pengembangan Modul Fisika pada Pokok Bahasan Listrik Dinamis Berbasis Domain Pengetahuan Sains untuk Mengoptimalkan Minds-On Siswa SMA Negeri 2 Purworejo Kelas X Tahun Pelajaran 2012/2013," RADIASI: Jurnal Berkala Pendidikan Fisika, Vol. 3, no. 1

Hamdani,. (2010). Strategi Belajar Mengajar (bandung: CV Pustaka Setia,

Indrawati Indrawati,. (2017). "Pengaruh Metode Scaffolding Berbasis Konstruktivisme terhadap Hasil Belajar Matematika," Journal of Medives: Journal of Mathematics Education IKIP Veteran Semarang 1, no. 1

Kurniati Annisah,. (2015). "Mengenalkan Matematika Terintegrasi Islam Kepada Anak Sejak Dini," Suska Journal of Mathematics Education, Vol. 1, no. 1

Kurniati Annisah,. (2016). "Pengembangan Modul Matematika Berbasis Kontekstual Terintegrasi Ilmu Keislaman," Al-Khwarizmi: Jurnal Pendidikan Matematika dan Ilmu Pengetahuan Alam, Vol. 4, no. 1

Mamin Ratnawati,. (2013). "Penerapan Metode Pembelajaran Scaffolding Pada Pokok Bahasan Sistem Periodik Unsur," CHEMICA, Vol. 9, no. 2

Mardiansyah Yopy,. (2013). "Pembuatan Modul Fisika Berbasis TIK untuk 
Mengintegrasikan Nilai Pendidikan Karakter dalam Pembelajaran Siswa SMAN 10 Padang Kelas X Semester 1," Pillar of Physics Education, Vol. 1, no. 1

Marsigit. (2010).Matematika SMA Kelas XII (jakarta: quadra,

Mina Syanti Lubis, R. Syahrul, dan Novia Juita,. (2014). "Pengembangan Modul Pembelajaran Bahasa Indonesia Berbantuan Peta Pikiran pada Materi Menulis Makalah Siswa Kelas Xi SMA/MA," Bahasa, Sastra, dan Pembelajaran 2, no. 1

Muthia dewi,. 2017. "pengembangan modul matematika menggunakan model Thiagarajan untuk meningkatkan kemampuan pemecahan masalah melalui pendekatan pembelajaran matematika realistic di $\mathrm{MtS}$ pesantren daar uluum kisaran, vol. 2, No. 1,

Ni Wayan Sutarmi, Naswan Suharsono, dan I. Wayan Sukra Warpala. (2013). "Pengaruh pembelajaran Scaffolding terhadap Keterampilan Menulis Teks Recount Berbahasa Inggris dan Kreativitas Siswa Kelas VIII SMP Negeri 3 Manggis," Jurnal Teknologi Pembelajaran Indonesia, Vol. 3,

Oni Arlitasari, Puja Pujayanto, dan Rini Budiharti. (2013). "Pengembangan Bahan Ajar Ipa Terpadu Bebasis Salingtemas dengan Tema Biomassa Sumber Energi Alternatif Terbarukan," Jurnal Pendidikan Fisika, Vol. 1, no. 1

Rizky Dezricha Fannie dan Rohati Rohati. (2014). "Pengembangan lembar kerja siswa (LKS) berbasis POE (predict, observe, explain) pada materi program linear kelas XII SMA," Sainmatika: Jurnal Sains dan Matematika Universitas Jambi, Vol. 8, no. 1

Salafudin Salafudi. (2015)., "Pembelajaran Matematika Yang Bermuatan Nilai Islam," Jurnal Penelitian, Vol, 12, no. 2

Sandiyanti Ageng. (2018). "Pengembangan Modul Bilingual Bergambar Berbasis Quantum Learning pada Materi Peluang," Desimal: Jurnal Matematika, Vol. 1, no. 2

Septora Rio. (2017). "Pengembangan Modul Dengan Menggunakan Pendekatan Saintifik Pada Kelas X Sekolah Menengah Atas," Jurnal Lentera Pendidikan Pusat Penelitian Lppm Um Metro, Vol. 2, no. 1

Septriani Nicke. (2014). "Pengaruh penerapan pendekatan scaffolding terhadap kemampuan pemahaman konsep matematika siswa kelas VIII SMP Pertiwi 2 Padang," Jurnal Pendidikan Matematika, Vol. 3, no. 3

Sofan Amri dan Alif Khoiru Ahmadi. (2010). Kontruksi Pengembangan Pembelajaran Pengaruhnya Terhadap Mekanisme dan Praktik Kurikulum (jakarta: PT. Prestasi Pustakaraya, 
Sugiyono. (2017). Metode Penelitian Pendidikan Kuantitatif, Kualitatif dan $R \& D$ (Bandung: Alfabeta,

sukino. (2017).Matematika Untuk SMA/MA Kelas XI Semester 1 (jakarta: erlangga,

Sumantri Mohamad Syarif,. (2016). Strategi Pembelajaran Teori Dan Praktik di Tingkat Pendidikan Dasar (jakarta: jarawali).

Supriadi Nanang. (2015). "Mengembangkan Kemampuan Koneksi Matematis Melalui Buku Ajar Elektronik Interaktif (BAEI) yang Terintegrasi Nilai-Nilai Keislaman," Al-Jabar: Jurnal Pendidikan Matematika, Vol. 6, no. 1

Syahrir Syahrir dan Susilawati Susilawati. (2015). "Pengembangan Modul Pembelajaran Matematika Siswa SMP," Jurnal Ilmiah Mandala Education (JIME), Vol. 1, no. 2

Syarifah Siti. (2017). "Pengembangan Lembar Kerja Peserta Didik (Lkpd) Berorientasi Nilai-Nilai Agama Islam Melalui Pendekatan Inkuiri Terbimbing Materi Trigonometri” (PhD Thesis, UIN Raden Intan Lampung)

Taza Nur Utami, Agus Jatmiko, dan Suherman Suherman. (2018). "Pengembangan Modul Matematika dengan Pendekatan Science, Technology, Engineering, And Mathematics (STEM) pada Materi Segiempat," Desimal: Jurnal Matematika, Vol. 1 , no. 2

Trianto. (2014).Model Pembelajaran Terpadu Konsep, Strategi dan Implementasi dalam Kurikulum Tingkat Satuan Pendidikan (Jakarta: Bumi Aksara,) 